\title{
Usefulness of Accounting Theory and Practices on Large Business Organizations in Nigeria
}

\author{
Osho, Augustine E. PhD \\ Akinola, Akinwumi $O$. \\ Department of Accounting, Achievers University, Owo, Nigeria
}

Doi:10.19044/esj.2018.v14n31p303 URL:http://dx.doi.org/10.19044/esj.2018.v14n31p303

\begin{abstract}
The study was about the impact of accounting theory and practice on performance of large scale business in Nigeria. The objective of the study was to examine the effect and usefulness of accounting theory and practice on financial performance of large firms. The research was carried out, using Coscharis Group Limited as the case study. Primary Data was collected through simple random sampling and using self-administered questionnaires for 20 respondents. Secondary Data was gotten from the company's annual reports on return on equity for the period 2014-2016. The primary and secondary data were consolidated for analysis. Multiple Linear Regression was used to analyze the data to test for the relationship between the accounting theory and practice variables (Positive Accounting Theory(PAT), Financial Reporting(FR), Auditing Practice (AP) and Budgeting) and Financial Performance(Return on Equity). Findings revealed that accounting theory and practice have significant relationship with the financial performance of large companies in Nigeria. It further shows that variables of accounting practice have significant effect on financial performance of large firms in Nigeria. It is recommended that quoted and unquoted organizations should ensure there is consistency in the accounting theory and practice adopted in preparation of their records to enhance stability in their financial performance.
\end{abstract}

Keywords: Accounting Practice, Accounting Theory, Auditing, Budgeting, Financial Performance, Financial Reporting, Return on Equity.

\subsection{Introduction}

According to Hendriksen (1982), accounting theory is defined as logical reasoning in the form of a set of broad principles that provide a general frame of reference by which accounting practice can be evaluated, and guide the development of new practices and procedures. The reality is that accounting theories provides a general frame of reference by which accounting 
professionals can be judged and also guide the way to development of new principles and procedure.

Theories sometimes give rise to misunderstanding, and may mean different things to different people. This arises because explanations are made at different levels. At one extreme, explanations are purely speculative, resulting in speculative theories. To the natural scientist, speculative theories are not generally theories at all and explanations have to be conclusive before they are given the status of theories. To this end, their assumptions require verification by the test of experience. Empirical theories are constructed by the process of verifying assumptions, or hypotheses, through the test of experience. This process is known as the scientific method (Glautier \& Underdown, 1997).

According to International Accounting Standard Board, (2008), "how organization present information in its financial statements is very important because financial statements are a central feature of financial reporting, and this is a principal means of communicating financial information to the various stakeholders aside from the investors".

Globalization and transnational business expansion has resulted in an increased need for uniform rules so that the financial statements in different countries are prepared on a similar basis, and there would be no opportunity for interpretation. Although, at an international level different professional accounting organizations have made efforts to harmonize financial reporting rules, there has been a lot of criticism on the address of financial statements for many reasons. Firstly, there are too many alternative ways to report financial information in the financial statements. This makes it difficult to compare the financial statements of different entities, and provides opportunities to false conclusions about the success of the activities of the entity. Secondly, the entities in different countries have different demands on how to draft financial statements (European Commission, 2011).

Financial reporting, which is a product of accounting practice, is very critical to ensuring the survival and growth of every business unit. The keeping of proper records and preparing of financial statements have enormous benefits for large Scale Enterprises which serve as an important management tool for every business because they provide an accurate reflection of financial performance of the business. It also serves as a means to monitor performance and measure the accuracy of income and expenditure. The keeping of accounting records involves the documentation of all the transactions of the business entity including its assets and capital (equity and liabilities), and in order to solve business limitations such as, lack of finance, weak institutional capacity, lack of managerial skills and training of small-scale enterprises, there is need for business management expertise to manage properly the finances, 
purchases, sales, production, and human resources aspect of the business (Adjei, Anokye, Mintah, \& Offeh, 2014).

According to IASB, (2007), financial reports in Nigeria are governed by regulations and standards from various recognised financial regulatory bodies such as the Securities and Exchange Commission (SEC), the Financial Accounting Reporting Council of Nigeria (FRCN), Nigerian Stock Exchange, etc. Financial reports are formal and comprehensive statements describing financial activities of a business organisation. It is also a statement that reports all relevant financial information, presented in a structured manner and in a form easy to understand for managerial use and for taking a prompt and informed decision relating to investment.

Over the years, accounting theories and practice have helped to fortify different assumptions and principles in the financial reporting policies of most organizations. However, despite this advantage, some researchers and globally recognized standard setting bodies, still see some of these accounting theories as conflicting. According to IASB, (2008), the presence of so many alternative in theories, has resulted in several criticism, and this has made it difficult to compare various organizations financial report. Also according to European Commission, (2011), most of the preparers of these financial reports do not give adequate consideration to the different peculiarities in some organizations operations before publishing most of these accounting theories, and this has made it difficult for these organizations to adopt these theories. Thus, this topic seeks to examine the effect of accounting theory and practice on the performance of large business organizations in Nigeria.

\subsection{Review of Literature}

\subsubsection{Concept of Accounting theory}

According to Glautier and Underdown (1978), a theory means general principles and ideas about a subject. The root of accounting theory stems from decision theory, measurement theory and information theory. Accounting theory has been and continues to be influenced by developments in other fields such as economics, and the behavioural sciences. They further stated that decision theory is partly descriptive and partly normative in nature. The former tries to explain how decisions are actually made while the latter attempts to throw light on how decisions ought to be made. On the other hand, measurement theory according to Glautier and Underdown (1978) holds the view that rational decision making depends on information or data, hence measurement to them implies assignment of rules specifying the property to be measured, the scale to be used and the dimension of the unit. 


\subsubsection{Concept of Accounting Practice}

Accounting practices are said to be the routine manner in which the day-to-day financial activities of a business entity are gathered and recorded. An accounting practice refers to the method by which its accounting policies are implemented and adhered to on routine basis, typically by an accountant and/or auditor or a team of accounting professionals. Accounting practices are intended to enforce accounting guidelines and policies. It exists as the daily recording of financial data that is important to the evaluation and monitoring of the economic activities. Accounting practice refers to the normal, practical application of accounting and/or auditing policies that occurs within a business entity (Pandey, 2008).

\subsubsection{Concept of financial Reporting}

Financial reporting involves recording and interpreting financial information in compliance with the relevant accounting standards. According to Vargiya, (2015), financial reporting includes the exposure of related financial information to the different Stakeholders about an organisation over a predefined timeframe. These Stakeholders include - investors, lenders, suppliers, and government organisations. Financial Reporting is considered as the final result of Accounting. It comprises of various important statement which include - financial related explanations from Statement of financial position, Statement of comprehensive income, Statement of cash flow, Statement of changes in equity, notes to financial related explanations, Quarterly and Annual reports, Prospectus and Management Discussion and Analysis.

According to International Accounting Standards Board, (2018), the objective of general purpose financial reporting is to provide financial information about the reporting entity that is useful to existing and potential investors, lenders and other creditors in making decisions about providing resources to the entity. Those decisions involve buying, selling or holding equity and debt instruments, and providing or settling loans and other forms of credit. Decisions by existing and potential investors about buying, selling or holding equity and debt instruments depend on the returns that they expect from an investment in those instruments, for example dividends, principal and interest payments or market price increases.

\subsubsection{Concept of Auditing}

Auditing is an independent examination and the expression of an opinion on the financial statements of an enterprise by an appointed auditor, in accordance with his terms of engagement and the observance of statutory regulations and professional requirements (Dandago, 1999 and Mainoma, 2007). This definition clearly stated that there must be someone (auditor) 
responsible for expressing an opinion on the entire financial statement of an organisation. The auditor here may mean an individual or firm carrying out the audit of an enterprise. The auditor should be approved and must have personal and operational independence in order to perform his duty effectively.

Akpata (2001) and Sabari, (2003), classifies audit into four: private, statutory, management and internal audit, even though all the types of audit focus on regulations, which lead to control of expenditure or revenue. Millichamp (2000) defined internal auditing as "an independent appraisal function within an organisation for the review of system of control and the quality of performance as a service to the organisation. It objectively examines, evaluates and reports on the adequacy of internal control system to the proper economic, efficient and effective use of resources".

\subsubsection{Concept of Budgeting}

Ezeamama,(2010) opines that growing complexity of the business environment and the ever increasing competition among firms in the modern time make planning an invaluable tool for business success. Successful management is no longer just a matter of flair skills and determination, a conscious effort is needed to harness available resources towards the achievement of enterprise objectives. He says that budgeting is one of the tools adopted by management for effective cost planning and control.

Pandey, (2008) on the other hand, states that, the common organizational goals includes maximizing profits and achieving satisfactory level of performance and performing a social service by providing goods and services desired by others. It is with a view of achieving their organizational goals that great emphasis is placed on budgeting. The budgeting process may be quite formal in a large organization with committees set up to perform that task. On the other hand in a small firm the owner jots down his budget on a piece of scrape paper or even on the back of a used envelope, some even manage without writing anything down at all they have done the budget in their heads and can easily remember them. When a plan is expressed quantitatively it is known as budget and the process of converting plans into budget is known as budgeting. Budgeting therefore is essentially a process of planning and control. He further argued that a well prepared budget provides management with a planning programme based on investigation study and research on the part of the entire organization.

\subsubsection{Concept of Profitability in Large Scale Business}

Profitability is the power of the enterprise to earn profits. Return on Investment (ROI) is a basic measure of profitability of a firm. It is a common yardstick to measure the effectiveness of the use of resources and it indicates 
the combined effects of liquidity, asset management and debt management on operating results (Verma, 1988).

The term 'profit' is viewed by different people in different perspectives. From the point of view of financial management profit is the test of efficiency and a measure of control, a measure of worth of investments to the owners, the margin of safety to the creditors, a source of fringe benefits to the employers, the measure of taxable capacity and the basis of legislative action to the government, a demand for price cut to the customers and finally to the country, an index to the economic progress, national income generation and rise in the standard of living.

According to Sharma and Gupta, (2006), profitability can be analysed based either on operating profits or net profit. It requires information from the financial statement, which has to be logically classified and compared in accordance with the objectives set. There are various techniques available for analysing profitability namely; Comparative Statements, Common-size Income Statement Analysis, Fund Flow Analysis, Trend Percentage Analysis and Ratio analysis. Profitability ratios are useful in analysing the profitability of a firm. The profitability ratios are broadly used for analysis by categorizing into two groups, namely.

(i) Profitability with reference to sales

(ii) Profitability with reference to Investment.

Profitability with reference to sales includes gross profit margin, operating profit margin and net profit margin while profitability with reference to investment includes return on total assets, return on net assets, return on shareholders' equity, and earnings per share.

\subsubsection{Measurement of financial performance}

There are various measures of financial performance. For example, return on assets (ROA) determines an organization's efficiency in the ability to make use of its assets and return on equity (ROE) reveals the returns investors expect to earn on their investments and return on sales (ROS) reveals how much a company earns in relation to its sales. The advantages of financial measures are the simplicity of calculation and also that their definitions are agreed worldwide. Traditionally, the success of a company has been evaluated by the use of financial measures (Tangen, 2003). Four useful measures of profitability are the rate of return on assets (ROA), the rate of return on equity (ROE), operating profit margin and net income. 


\subsubsection{Conceptual Framework on Usefulness of Accounting Theory and} Practices on Large Business Organizations in Nigeria

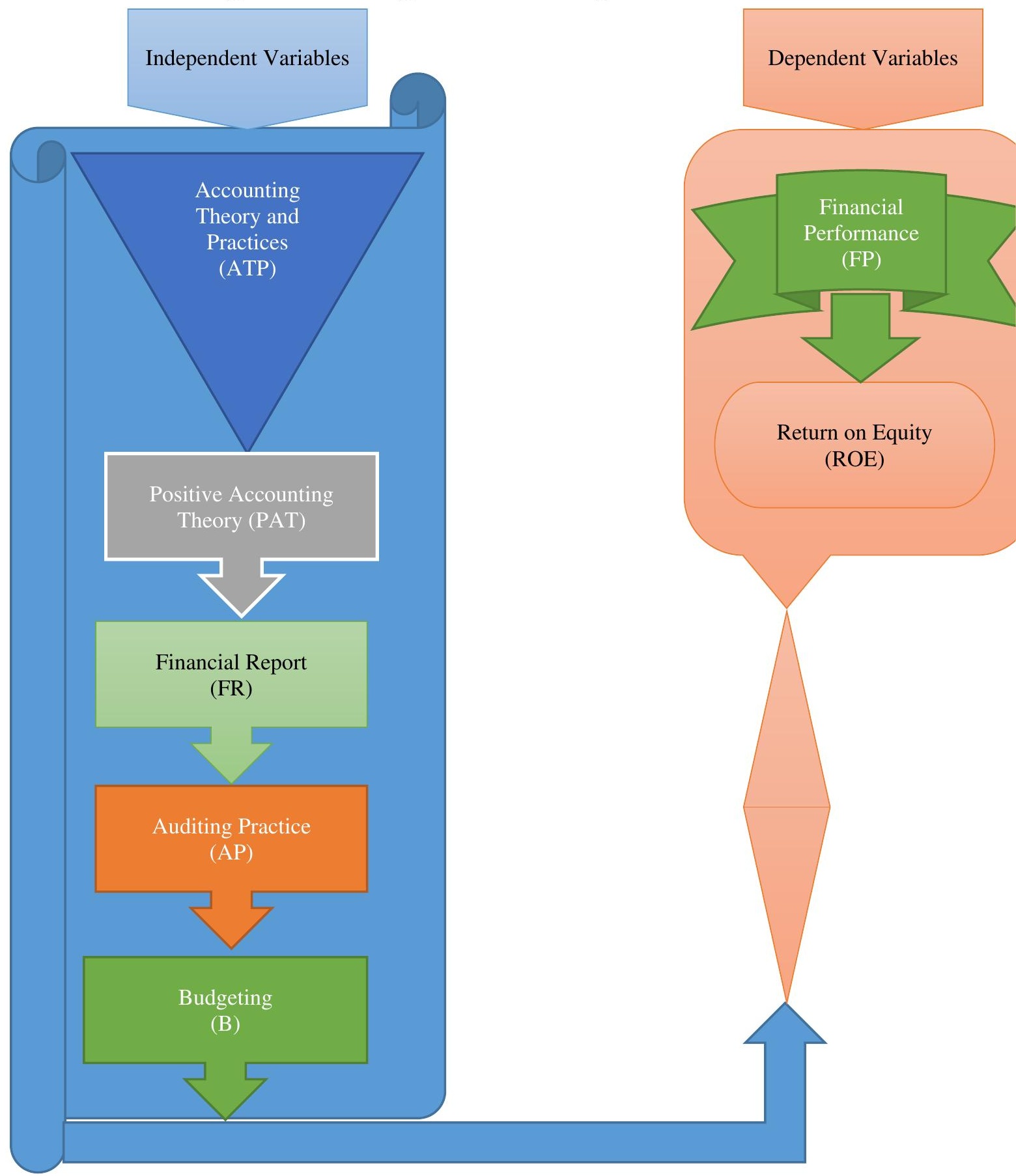

Fig. 1.0 Researchers' Usefulness of Accounting Theory and Practices on Large Business Organizations in Nigeria Model 


\subsection{Theoretical Framework}

\subsubsection{Positive Accounting Theory}

Positive Accounting Theory (PAT) provides a refreshing, controversial and important contribution to accounting thought. It is important because of its vigorous emphasis on the entity's actual choice of financial accounting technique (or, more broadly, financial reporting activity). It is controversial because the theory and empirical techniques it conveys are not fully developed. It is refreshing because it challenges us to expand our thinking about the nature of accounting institutions (Budkov \& Kolesnikov, 2016).

In positive accounting theory, academics view a company as the total of the contracts they have entered into. The theory posits that, because companies are fundamentally about the contracts that dictate its business, a core driver of company success is efficiency. That means minimizing the costs of its contracts to unlock the most value from them. From that basis, positive accounting examines real life occurrences and seeks to understand and then predict how companies address the accounting treatment of those transactions. In other words, positive accounting theory looks at real world transactions and events, examines how companies are accounting for those events, and seeks to understand the economic consequences of those accounting decisions (Watts \& Zimmerman 1990).

\subsubsection{Normative Theory}

Normative accounting theory, popularly known as normative methodology also, attempts to prescribe what data ought to be communicated and how they ought to be presented; that is, they attempt to explain 'what should be' rather than 'what is.' Financial accounting theory is predominantly normative (prescriptive). Most writers are concerned with what the contents of published financial statements should be; that is, how firms should account. It has been found that government regulations relating to accounting and reporting has acted as a major force in creating a demand for normative accounting theories employing public interest arguments, that is, for theories purporting to demonstrate that certain accounting procedures should be used, because they lead to better decisions by investors and more efficient capital market (Mootze, 1970).

\subsubsection{Stewardship Theory}

The Stewardship theory can also be said to be a product of the seminar work done by (Donaldson \& Davis 1989). This work emphasized that the senior executives should act as steward of the organisation and that everything is done in the best interest of the principal. This explanation of stewardship theory put forward by them established that most managers tend to act in the best interest of their firm, by emphasising the collective goal of the 
organisation instead of their self-serving option. Their finding further suggests that most stewards are motivated only by making the right decision which is usually in the best interest of the organisation, because of the strong assumption that stewards will also benefit from the right decision taken in the long run.

Similarly, Davis, Schoorman and Donaldson (1997) define stewardship theory as the process where stewards protect and maximize shareholders wealth through improved firm's performance, because by doing so, the stewards recognised, that his utility function is maximized. This stewardship theory refers more to the manager and chief executive as the main individual responsible for the stewardship function in the organisation.

\subsubsection{Stakeholder's Theory}

According to Freeman (1994), stakeholder theory emphasizes that some individuals or groups are very important for the survival of the organization. This explanation is seen as organisation oriented explanation, but in an earlier research freeman reported that stakeholder theory refers to any group or individual who can affect or who is likely to be affected by the achievement of the organisation objective. The stakeholder in most organisations usually includes shareholders, employees, customers, lenders, suppliers, local charities, various interest group and government.

Stakeholder theory attempts to describe, prescribe, and derive alternatives for corporate governance that included and balanced a multitude of interests. The theory has drawn considerable attention and support since its early formulation. Stakeholder theory incorporates the executive power model, which claimed that the purpose of a corporation is the maximisation of corporate wealth. However, this intensified the problem of directors acting in their own self-interest, as they support policies that led to the protection of their positions and powers in the company (Kay \& Silberston, 1995).

Indeed, the executive power model claimed that the purpose of corporation is the maximisation of stakeholders' wealth as a whole. However, this involved the absence of stakeholder involvement in the running of the company, giving directors the opportunities to push policies that do not take the needs of the company's stakeholders into consideration, (Freeman, 1984).

\subsubsection{Asymmetric Theory}

Akerlof, (1970) opined that imbalances in access to information can easily influence the capital market for the trading of merchandise and business. It says that in some financial transactions, disparities in access to information annoy the ordinary market for the trading of merchandise and business. This theory gives a hypothetical clarification of the weight to unveil on the executives of the banks who are better put in the corporate structure to know 
the banks better and along these lines discharge the information they have to the financial specialists that will utilize same for basic leadership.

Ball, (2009) took note of the reviewed financial related articulations and intentional exposures which were corresponding systems for directors to impart information. Gigler and Hemmer, (1998) watched that, reporting autonomously inspected financial results play a 'corroborative part', enabling shareholders to assess the education and honesty of past optional disclosures. Thus, this enables directors to solidly reveal value applicable information, regardless of the possibility that the information is not specifically unquestionable.

\subsubsection{Voluntary Disclosure Theory}

The thought of theory of Voluntary Disclosure emphasizes that, even without control, managers still wish to reveal extra information. This is because in the light of contemplations found in organisation theory, which affirm that agency expenses are borne for the most part by agent (Jensen \& Meckling, 1976). Along these lines, operators attempt to diminish their agency expenses to augment their riches. As depicted in organization theory, agent expenses are a result of information asymmetry, whereby the specialist has more private information about the organisation's performance than the essential.

The SEC and the FASB give rules to obligatory revelations; the exposure writing in accounting alludes to deliberate and optional disclosures, conversely, as information management discharges itself. The hidden supposition in the disclosure writing is the administrator has better information than others. The outcome is executives' exchange off between settling on accounting decisions and giving revelations to "convey their better information of an organisation's performance than financial specialists, and to oversee announced performance for contracting, political, or corporate management reasons" (Healy \& Palepu, 2001).

\subsection{Empirical Review}

Adjei et al, (2014), assessed Financial Reporting Practices among Small Scale Enterprises. The aim of the research was to assess the financial reporting practices among small scale enterprises. The study further considered the problems faced by Small Scale Enterprises in preparing financial reports. The researchers used both qualitative and quantitative method, supported by statistical analysis of the survey data. The primary instruments used to collect data were interviews, observation and questionnaire. The findings confirmed that there is poor financial record keeping and financial reporting practices among small scale enterprise and recommends that training programmes be 
organized for small scale enterprises to help them appreciate the importance of financial reporting and inculcate such practices in them.

Similarly, Maseko and Manyani, (2011), carried out a study on "Accounting practices of SMEs in Zimbabwe" using Bindura as a case. The survey research design was used. The targeted population comprised of 100 SMEs operating retail shops, manufacturing firms and suppliers of various services in Bindura. A structured questionnaire was used to collect primary data from the respondents which were analysed to generate frequencies and percentages. The study revealed that the majority of SMEs do not keep complete accounting records due to lack of accounting knowledge and as a result this, there is inefficient use of accounting information in financial performance measurement. The study recommended that national regulators should develop specific accounting guidelines for SMEs and develop accounting training programmes for entrepreneurs in small businesses. The study also recommended mandatory record keeping, to improve accounting practices of SMEs in Zimbabwe.

Boame, Kudadze, and Sulemana, (2014) studied the "Adoption of Accounting Practices and Its Effects on SMEs: Financial Perspective of Sachet Water Producers in Northern Region of Ghana". The prime drive for this study was to know their adoption to accounting practices, the challenges they encounter, the factors that influence their adoption and to make recommendations in that regard. A qualitative research design was employed and for the study a non-probability sampling design in the form of a convenience sampling method was employed to gather the data. Data were drawn from both primary and secondary sources. Primary data was drawn from 30 registered small scale sachet water producers (5 each in North, South, East and Central constituencies of Tamale Metropolis) of the Northern Sachet Water Producing Association by administering semi-structured questionnaires and personal interviews. The study found that, there are many perceived factors affecting their adoption of accounting practices as well as their effects on their business operations in the area. Among such factors were; lack of adequate training, wilful misconduct and negligence. The study also revealed that, illiteracy was the root cause of making it very difficult, if not impossible for them to separate personal expenditure from business expenditure. The study also found that, Non-documentation of cash sales, error of principle, and incomplete entry, etc. were found to be on high side, because almost all the operators have no accounting background. It was further identified that enterprises whose accounting records were beset with challenges, lack the credit worthiness of accessing loans and funding for further investments and growth and concluded that, lack of accounting knowledge and skills may in the future threaten the financial steadiness of the water producing sector and in order to continually sustaining the sector, the findings recommends that, the 
operators undergo basic accounting training to acquire relevant knowledge and skills, employ qualified accounting personnel and providing them with good motivational packages to ensure that their efficiency and morale is enhanced, and at the same time, maintain strong internal control system to curtail the practice of misappropriating the business funds.

\subsection{Methodology}

This study used both primary and secondary sources of data. For the primary source of data, survey research was used to ensure originality and reliability. This is a method of gathering data from respondents through the representative of the population using an instrument composed of administered questionnaire. 20 copies of the questionnaire were distributed to the staff of account department in Coscharis Group Limited. For the secondary data, the study utilized data gotten from relevant journals, articles and seminar papers. Data on the company's return on equity was extracted. Multiple regression analysis was employed as a means of testing the impact of accounting theory and practices on large scale business performance.

\section{Model Specification}

In this study, the model shall contain two equations. Whilst the first is on determinant of accounting theory and practices in a business organization, the second is on impact of accounting theory and practices (ATP) on financial performance using Positive Accounting Theory (PAT), Financial Reporting (FR), Auditing Practice (AP) and Budgeting $\left(\mathrm{B}_{\mathrm{u}}\right)$ as the independent variables and regressed against the dependent variable Return on Equity (ROE) used as proxy for financial performance.

The model used will be expressed mathematically as thus:

Equation One and two can written as

$\mathrm{ATPs}=\left\{\mathrm{PAT}, \mathrm{FR}, \mathrm{AP}, \mathrm{B}_{\mathrm{u}}\right\}$

$\mathrm{ROE}=\mathrm{f}\left\{\mathrm{PAT}, \mathrm{FR}, \mathrm{AP}, \mathrm{B}_{\mathrm{u}}\right\}$

Multivariate Regression model would be; $Y=\alpha+\beta_{1} X_{1}+\beta_{2} X_{2}+\beta_{3} X_{3}+$ $\beta_{4} \mathrm{X}_{4} \ldots \ldots \ldots+\beta \mathrm{nXn}+\varepsilon$

Thus, Regression equation becomes; ROE $=\boldsymbol{\alpha}+\boldsymbol{\beta}_{1}[\mathbf{P A T}]+\boldsymbol{\beta}_{2}[\mathbf{F R}]+$ $\beta_{3}[\mathrm{AP}]+\boldsymbol{\beta}_{4}\left[\mathrm{~B}_{\mathrm{u}}\right]+\boldsymbol{\varepsilon}$

where $Y=$ the value of dependent variables; $\alpha=$ the constant term; $\beta=$ the coefficient of the function; $X=$ the value of independent variables; and $\mathrm{e}=$ error term.

\subsection{Analysis and Findings \\ 4.1 Test of hypothesis}

Accounting Theory and Practice does not have significant impact on performance of large scale companies in Nigeria. 


\begin{tabular}{|c|c|c|c|c|}
\hline \multicolumn{5}{|c|}{ Model Summary } \\
\hline Model & R & R Square & Adjusted R Square & Std. Error of the Estimate \\
\hline 1 & $.940^{\mathrm{a}}$ & .884 & .855 & 254195.302 \\
\hline a. Predictors: (Constant), Positive Accounting Theory, Financial Reporting, Auditing Practice, \\
Budgeting \\
\hline \multicolumn{5}{|c}{ b. Dependent Variable: Return on Equity } \\
\hline
\end{tabular}

Source: Researchers' SPSS Analysis Output.

\begin{tabular}{|c|c|c|r|r|r|c|}
\hline \multicolumn{7}{|c|}{ ANOVA $^{\mathrm{a}}$} \\
\hline \multicolumn{2}{|c|}{ Model } & Sum of Squares & Df & Mean Square & F & Sig. \\
\hline \multirow{2}{*}{1} & Regression & 5913342761680.730 & 3 & 1971114253893.577 & 30.505 & $.001^{\mathrm{b}}$ \\
\cline { 2 - 7 } & Residual & 775383021322.805 & 12 & 64615251776.900 & & \\
\cline { 2 - 7 } & Total & 6688725783003.535 & 15 & & \\
\hline \multicolumn{7}{|c|}{ a. Dependent Variable: Return on Equity } \\
\hline \multicolumn{7}{|c|}{ b. Predictors: (Constant), Positive Accounting Theory, Financial Reporting, Auditing Practice, } \\
Budgeting.
\end{tabular}

Source: Researchers' SPSS Analysis Output.

\begin{tabular}{|c|c|c|c|c|c|c|}
\hline \multicolumn{7}{|c|}{ Coefficients } \\
\hline \multirow{2}{*}{\multicolumn{2}{|c|}{ Model }} & \multicolumn{2}{|c|}{$\begin{array}{l}\text { Unstandardized } \\
\text { Coefficients }\end{array}$} & \multirow{2}{*}{$\begin{array}{c}\begin{array}{c}\text { Standardized } \\
\text { Coefficients }\end{array} \\
\text { Beta }\end{array}$} & \multirow[t]{2}{*}{$\mathbf{T}$} & \multirow[t]{2}{*}{ Sig. } \\
\hline & & B & Std. Error & & & \\
\hline \multirow{5}{*}{1} & (Constant) & 220357.746 & 143969.759 & & 1.531 & .152 \\
\hline & Positive Accounting Theory & .087 & .027 & .361 & 3.240 & .004 \\
\hline & Financial Reporting & 1.637 & .311 & .658 & 5.266 & .000 \\
\hline & Auditing Practice & .001 & .001 & .121 & 1.080 & .001 \\
\hline & Budgeting & .140 & .038 & .605 & .062 & .002 \\
\hline
\end{tabular}

Source: Researchers' SPSS Analysis Output.

\subsection{Interpretation and discussion of results}

From the model summary, the R-squared (0.884) which is the multiple coefficient of determination gives the proportion or percentage of the total variation in the dependent variable explained by the explanatory variables jointly. Hence, it signifies 88.4 per cent of the total variation in Return on Equity is caused by Positive Accounting Theory, Financial Reporting, Auditing Practice and Budgeting. This indicates that the Model is fit and the explanatory variables are properly selected and used. This also indicates that 88.4 per cent of the variation has been accounted for and that only 11.6 per cent of the variations were due to error. According to Mafini and Meyer, (2016), R-squared is a statistical measure of how close the data are to the fitted regression model and this is indicated by the percentage of variance. The higher the percentage of variance accounted for by the regression model, the closer it is to a perfect model fit of 100 per cent. 
From the regression table, the coefficient of the independent variables in the model are positively and statistically significant which implies that financial performance of large scale organizations are significantly affected by accounting theory and practices adopted. Furthermore, the result of the analysis of variance statistics (ANOVA) also lends credibility to the fact that an increase in the use of accounting theory and practice will lead to significant changes in the financial performance of companies. This is because, the Fstatistics obtained (i.e 30.505) is higher than the F-tabulated of 3,12 (df) i.e 3.49 .

Hence, according to the decision rule the null hypothesis will be rejected while the Alternate hypothesis will be accepted. This means that Accounting Theory and Practice have significant impact on performance of large scale companies in Nigeria.

\subsection{Summary and Conclusion}

The finding of this study confirms that accounting theory has significant relationship with the financial performance of large companies in Nigeria. This is because positive accounting theory has significant impact on financial performance, and this was confirmed by the P-value obtained (0.004) from the statistical analysis. The findings of the study also shows that variables of accounting practice have significant effect financial performance of large firms, because their respective P-values obtained were lower than the benchmark value of $5 \%$ specified in this analysis. The study therefore, validates that accounting theory and practices such as positive accounting theory, financial reporting, auditing practice and budgeting are instrumental in stimulating the large scale business performance in Nigeria.

Thus, from the conclusion drawn, the study makes the following recommendations:

Quoted and Unquoted organizations should ensure there are consistencies in the accounting theory and practice adopted in preparation of their records to enhance stability in their financial performance, since this study has established statistically that accounting theory and practice have significant relationship with financial performance.

Also, companies must ensure that accounting theories and practices adopted by them are not contradictory, that is, they must adopted accounting theory and practices that are comparable with companies that are in same line of business with them.

Companies are also advised to engage professionals in the process of preparation, presentation and audit of their financial statements in line with current practices in Nigeria and in compliance with relevant standards and frameworks. 


\section{References:}

1. Adjei, H, Anokye, O. A., Mintah, E. K., \& Offeh, M. C. (2014). Assessing Financial Reporting Practices among Small Scale Enterprises in Kumasi Metropolitan Assembly. European Journal of Business and Social Sciences. 2(10).

2. Akerlof, G.A., (2004). The market for Lemons. Quality, Uncertainty and Market. Mechanism. The Quarterly Journal of Economics: 84.(3) 488-500.

3. Akerlof, G.A. , (1970)“The market for „Lemons". Quality, Uncertainty and Market. Mechanismee, The Quarterly Journal of Economics, 84.(3) 488-500.Akpata, J. M. (2001), "Internal auditing: Principles and practice". The National Accountants Journals. 9 (3), July-Dec., ESS \& TEE Product, Lagos.

4. Ball, R. (2009). Infrastructure Requirements for an Economically Efficient System of Public Financial Reporting and Disclosure. Brookings - Wharton papers on Financial Services. 69-127.

5. Boame, I., Kudadze, S. \& Sulemana, I. (2014). Adoption of Accounting Practices and Its Effects on SMEs: Financial Perspective of Sachet Water Producers in Northern Region of Ghana. Research Journal of Finance and Accounting, 5(17), 166-180.

6. Budkov, Y. A. \& Kolesnikov, A. L., (2016). On the theory of electric double layer with explicit account of a polarisable co-solvent.144(18).

7. Dandago, K. I. (1999). Auditing in Nigeria: A comprehensive text. 1st Edition, Kano: Adamu Joji Publishers.

8. Davis, J. H., Schoorman, F. D \& Donaldson, L., (1997). Toward a Stewardship. Theory of Management Review, 22(1), 20-47.

9. Donaldson, L. and Davis, J. H. (1989). CEO Governance and Shareholder Returns: Agency Theory or Stewardship Theory. Paper Presented at the Annual Meeting of the Academy of Management.

10. European Commission, (2011). Financial reporting obligations for limited liability companies (Accounting Directive): frequently asked questions.

11. Ezeamama M.C (2010), Fundamentals of Financial Management. Enugu; Emma publishers.

12. Freeman, R.E., (1984) Strategic Management: A Stakeholder Theory' Journal of Management Studies 39(1): 1-21.

13. Freeman, R.E. (1994), "The Politics of Stakeholder Theory: Some Future Directions," Business Ethics Quarterly, 4(4), pp. 409-422.

14. Glautier, M. W \& Underdown, B. (1978) Accounting theory and practice, London; Pitman publishing ltd.

15. Glautier, E. \& Underdown, B. (1997). Accounting Theory and Practice. (5th ed.). London, UK: Pitman Publishing. 
16. Gigler, F., Hemmer, T., (1998). On the frequency, quality, and informational role of mandatory financial reports. Journal of Accounting Research 36 (Suppl.), 117-147.

17. Healy, P.M., \& Palepu, K.G. (2001). Information asymmetry, corporate disclosure, and the capital markets: A review of the empirical disclosure literature. Journal of Accounting and Economics, 31, 405-440.

18. Hendriksen, E.S. (1982). Accounting Theory. Illinois, Homewood: Irwin.

19. IASB, (2007). Presentation of Financial Statement. Standard IAS 1, International Accounting Standards Board. Retrieved from: http://www.iasplus.com/standard/ias01.htm

20. International Accounting Standards Board, (2008). Exposure Draft on an Improved Conceptual Framework for Financial Reporting: The Objective of Financial Reporting and Qualitative Characteristics of Decision-Useful Financial Reporting Information. London: IASB, 164.

21. International Accounting Standards Board, (2018). Conceptual Framework for Financial Reporting. United Kingdom: IASB.

22. Jenson, M. C. and Meckling W. H. (1976), "Theory of the Firm: Management Incentives", Journal of Political Economy 98(2), 225235.

23. Kay, J. and Silberston, A. (1995), "Corporate Governance", National Institute Economic Review, 84 (August), 84-97.

24. Mafini, C \& Meyer, D (2016). Societal Factors and Life Satisfaction: Evidence from Low Income Urban Societies in a Developing Country, Journal of Economics and Behavioral Studies, 8(3), pp. 8710.

25. Mainoma, M. A. (2007). Financial control and management: A paper presented at ANAN: Mandatory Continuing Professional Development(MCPD).

26. Maseko, N. \& Manyani, O. (2011). Accounting practices of SMEs in Zimbabwe: An investigative study of record keeping for performance measurement (A case study of Bindura). Journal of Accounting and Taxation, 3(8), 171-181.

27. Millichamp, A. H. (2000) . Auditing , 7th Edition. London: Continuum.

28. Mootze M, (1970), Three contributions to the development of Accounting principles prior to 1930, Journal of Accounting Research, AAA. 8(1) 145-155.

29. Sabari, M.H. (2003). Internal auditor as a custodian of internal control. In Dandago, K.I. and Tanko, A.I (eds), Background Issues to Ethic in 
Accounting, Proceeding of the first annual conference on ethical issues in accounting Vol 1, Department of Accounting, BUK.

30. Pandey I.M, (2008). Management Accounting. Third revised edition Dehil, Jitendra printing press.

31. Tangen, S (2003) "An overview of frequently used performance measures", Work Study, Vol. 52 Issue: 7, pp.347-354.

32. Vargiya, (2015). Financial Reporting. Retrieved from: http://www.edupristine.com/blog/financial- reporting.

33. Verma, B.L., (1988). Analysis of Financial Statement, Jaipur, Arihant Publishers: 97-100.

34. Sharma, S. \& Gupta, K., (2006) Management Accounting, Kalyani Publishers, pp. 88-94.

35. Watts, R. \& Zimmerman J. (1990). Positive Accounting Theory: A Ten Year Perspective. The Accounting Review, 2(3), 131-156. 